\title{
Exploring video and eDNA metabarcoding methods to assess oyster aquaculture cages as fish habitat
}

\author{
Renee Mercaldo-Allen ${ }^{1}$, Paul Clark ${ }^{1}$, Yuan Liu ${ }^{1,2}$, Gillian Phillips ${ }^{1,2}$ Dylan Redman ${ }^{1}$, \\ Peter J. Auster ${ }^{3}$, Erick Estela ${ }^{1}$, Lisa Milke ${ }^{1}$, Alison Verkade ${ }^{4}$, Julie M. Rose ${ }^{1, *}$ \\ ${ }^{1}$ NOAA Fisheries, Northeast Fisheries Science Center, Milford Laboratory, 212 Rogers Avenue, Milford, CT 06460, USA \\ ${ }^{2}$ A.I.S. Inc., 540 Hawthorn Street, North Dartmouth, MA 02747, USA \\ ${ }^{3}$ University of Connecticut Department of Marine Sciences \& Mystic Aquarium, 1080 Shennecossett Road, Groton, CT 06340, USA \\ ${ }^{4}$ NOAA Fisheries, Greater Atlantic Regional Fisheries Office, Habitat Conservation Division, 55 Great Republic Drive \\ Gloucester, MA 01930, USA
}

\begin{abstract}
Multi-tiered oyster aquaculture cages may provide habitat for fish assemblages similar to natural structured seafloor. Methods were developed to assess fish assemblages associated with aquaculture gear and boulder habitat using underwater video census combined with environmental DNA (eDNA) metabarcoding. Action cameras were mounted on 3 aquaculture cages at a commercial eastern oyster Crassostrea virginica farm ('cage') and among 3 boulders on a natural rock reef ('boulder') from June to August 2017 in Long Island Sound, USA. Interval and continuous video recording strategies were tested. During interval recording, cameras collected $8 \mathrm{~min}$ video segments hourly from 07:00 to 19:00 h on cages only. Continuous video was also collected for $2-3 \mathrm{~h}$ on oyster cages and boulders. Data loggers recorded light intensity and current speed. Seawater was collected for eDNA metabarcoding on the reef and farm. MaxN measurements of fish abundance were calculated in video, and 7 fish species were observed. Black sea bass Centropristis striata, cunner Tautogolabrus adspersus, scup Stenotomus chrysops, and tautog Tautoga onitis were the most abundant species observed in both oyster cage and boulder videos. In continuous video, black sea bass, scup, and tautog were observed more frequently and at higher abundance on the cage farm, while cunner were observed more frequently and at higher abundance on boulders within the rock reef. eDNA metabarcoding detected 42 fish species at the farm and reef. Six species were detected using both methods. Applied in tandem, video recording and eDNA provided a comprehensive approach for describing fish assemblages in difficult to sample structured oyster aquaculture and boulder habitats.
\end{abstract}

KEY WORDS: Oyster aquaculture cages $\cdot$ Boulders $\cdot$ Rock reef $\cdot$ Video $\cdot$ eDNA $\cdot$ Environmental DNA $\cdot$ MaxN $\cdot$ Finfish

\section{INTRODUCTION}

Oyster aquaculture cages contribute structure to marine environments and may provide valuable habitat for ecologically and economically important species of fish. Multi-tiered cages, where oysters are grown in mesh bags on shelves or placed loose in stacked trays, produce more shellfish on a smaller spatial footprint than do traditional on-bottom cultivation methods and are increasingly used to culture

\footnotetext{
${ }^{*}$ Corresponding author: julie.rose@noaa.gov
}

oysters in coastal waters of New England, USA (Getchis 2005, Archer et al. 2014, Scuderi \& Chen 2019). Cage structures, composed of vertical relief and interstitial spaces, may confer a variety of benefits to fish including shelter from predation, refuge from high current flow, and focal habitat for courtship and mating activity, and thus may increase the number of individuals or species present in a given area (García-Charton \& Pérez-Ruzafa 1998). Over time, cage surfaces become colonized by epibenthic

() The authors 2021. Open Access under Creative Commons by Attribution Licence. Use, distribution and reproduction are unrestricted. Authors and original publication must be credited. 
fauna and macroalgae that provide additional structure and a food source for fish and invertebrates (e.g. Shumway et al. 2003, DeAlteris et al. 2004, Forrest et al. 2009). Shellfish farms with high cage densities may act like artificial reefs, creating islands of structure on otherwise featureless seafloor that can augment existing fish habitat (DeAlteris et al. 2004, Marenghi et al. 2010). Shellfish growers routinely report fish moving in and around aquaculture gear, generating sustained interest in oyster cages as fish habitat. Traditional sampling methods (e.g. lift or drop net, fish traps, quadrats, suction dredge) are difficult to employ in structured habitats, but previous studies suggest that oyster cages create habitat that is functionally similar to natural structured seafloor (e.g. DeAlteris et al. 2004, Tallman \& Forrester 2007, Erbland \& Ozbay 2008, Marenghi et al. 2010, MercaldoAllen et al. 2020). These studies support a strong association between the presence of structure-oriented fish species and oyster cages, but lack direct visual observation of fish interactions with cages, and therefore provide limited insight into composition of fish assemblages and fish abundance and behavior in and around aquaculture gear.

Use of underwater video is an effective and widely accepted strategy for viewing fish activity in benthic marine habitats (e.g. Letessier et al. 2015, Ulrich \& Bonar 2020). Self-contained action video cameras are small, relatively inexpensive, easy to use, produce good quality video, and can support high speed and capacity memory media (e.g. SDHC or SDXC cards based on current technology) (Letessier et al. 2015, Zarco-Perello \& Enríquez 2019, Ulrich \& Bonar 2020). Video offers an advantage over traditional visual diver surveys for estimation of fish abundance, which are subject to time and depth limitations, variability among human observers, and may disrupt natural patterns of fish activity (e.g. Willis \& Babcock 2000, Watson et al. 2010). Recorded video footage produces a permanent archive of fish activity that can be returned to for repeated analysis, verification, and review (Zarco-Perello \& Enríquez 2019). Visual observations may provide valuable information on how fish utilize aquaculture cage and boulder structures (behavior), which species associate with cages and boulders (community composition), how many fish are using cages or boulders simultaneously (index of abundance), and patterns of fish activity on a daily and seasonal cycle (temporal variation). Video methods are particularly effective for monitoring structure-oriented temperate reef species that demonstrate high site fidelity and are not easily sampled by traditional methods such as trawling (Cullen \& Stevens 2017). Visually documenting fish assemblages associated with oyster cages in comparison to natural, structurally complex habitats (e.g. boulder reefs) may provide data on the use of aquaculture gear as habitat by fish that can inform permitting and regulatory decision making and contribute to the broader public discussion around shellfish farming in coastal communities.

Fish may respond to fluctuations in environmental conditions - such as current velocity and light intensity - that exhibit diurnal patterns. Oscillations in current speed and direction occur twice daily commensurate with tidal cycles in Long Island Sound, USA. When water flow reverses direction with incoming or outgoing tides, fish that orient into currents may alter position relative to cages or boulders. Changing current velocities can affect small-scale spatial distribution of fish species in certain size classes (Auster 1987). Fish may seek out seafloor structure and bottom features as shelter from swift current flow (Auster 1987, 1989, Auster et al. 2003). Tide- or wind-generated currents may influence the abundance of fish and number of species that are observed in video (Whitmarsh et al. 2018). Light attenuation in bottom habitats can also vary depending on time of day, season, cloud conditions, tidal cycle, turbidity, depth, wave action, and water clarity (Stoner 2004), and confound the ability to view and identify fish in underwater video (Geraldi et al. 2019). Comparison of video footage collected adjacent to oyster cages and/or structured boulder habitat with concurrent measurements of current speed and light intensity may help discern whether patterns of fish abundance relate to variable environmental conditions.

Environmental DNA (eDNA) metabarcoding is an emerging tool that uses traces of DNA shed by fish (e.g. scales, mucus, feces) to document the occurrence of finfish species in the aquatic environment (e.g. Thomsen et al. 2012, O'Donnell et al. 2017, Liu et al. 2019). eDNA metabarcoding may be useful to detect fish that associate with cages or boulders but are not likely to be observed in video, perhaps due to their functional role or trophic group (grazer, predator), location in the water column (benthic, demersal, pelagic), or temporal patterns of activity (diurnal or nocturnal). Descriptions of fish assemblages, based on eDNA results, have compared favorably with species composition determined by conventional fish survey methods and can be obtained without reliance on expertise in fish taxonomy or sampling restrictions associated with structured seafloor (Thomsen et al. 2012, Liu et al. 2019). Application of eDNA metabarcoding for identification of fish species has been shown to ef- 
fectively discern community composition in estuaries (e.g. O'Donnell et al. 2017, Stoeckle et al. 2017, Yamamoto et al. 2017) and like video, may have particular value in complex habitats that are otherwise difficult to sample such as aquaculture farms and reef habitats (Rees et al. 2014, Stoeckle et al. 2017, Stat et al. 2019). Recent evidence also suggests that read counts obtained from eDNA metabarcoding can be significantly correlated with fish biomass and/or abundance in both freshwater (Di Muri et al. 2020) and marine (Stoeckle et al. 2021) environments.

The objective of this work was to investigate finfish community structure and dynamics in order to evaluate the potential habitat value of aquaculture gear compared to natural structured habitats. Boulders were chosen as the control for these experiments as rock reefs are likely to provide the most similar type of natural structured habitats in this region to that provided by aquaculture cage farms. Here, we present an evaluation of both video collection and eDNA metabarcoding methodology to document fish assemblages associated with aquaculture gear and comparable nearby structured habitat. We applied these methods on oyster aquaculture cages at a commercial shellfish farm and amongst boulders on a natural rock reef in Long Island Sound off coastal Connecticut, USA (NW Atlantic). We compared the information obtained from each method and assessed the value of using both tools in tandem to assess fish presence and abundance or biomass associated with oyster aquaculture gear and rock reef habitat in the nearshore environment. We also qualitatively identified organisms growing on boulders and oyster cages that may have contributed to their value as fish habitat.

\section{MATERIALS AND METHODS}

\subsection{Study sites}

Our study was conducted in Long Island Sound, off the coast of Milford, Connecticut, USA (Fig. 1). Sites included an on-bottom eastern oyster Crassostrea virginica aquaculture cage farm (cage farm) and a natural cobble and boulder reef (rock reef). Three study cages were added to an active commercial shellfish farm that already contained $40+$ oyster aquaculture shelf-and-bag style bottom cages. This farm was located on a $0.11 \mathrm{~km}^{2}$ shellfish lease permitted for up to 200 cages. An adjacent $0.25 \mathrm{~km}^{2}$ lease with 100

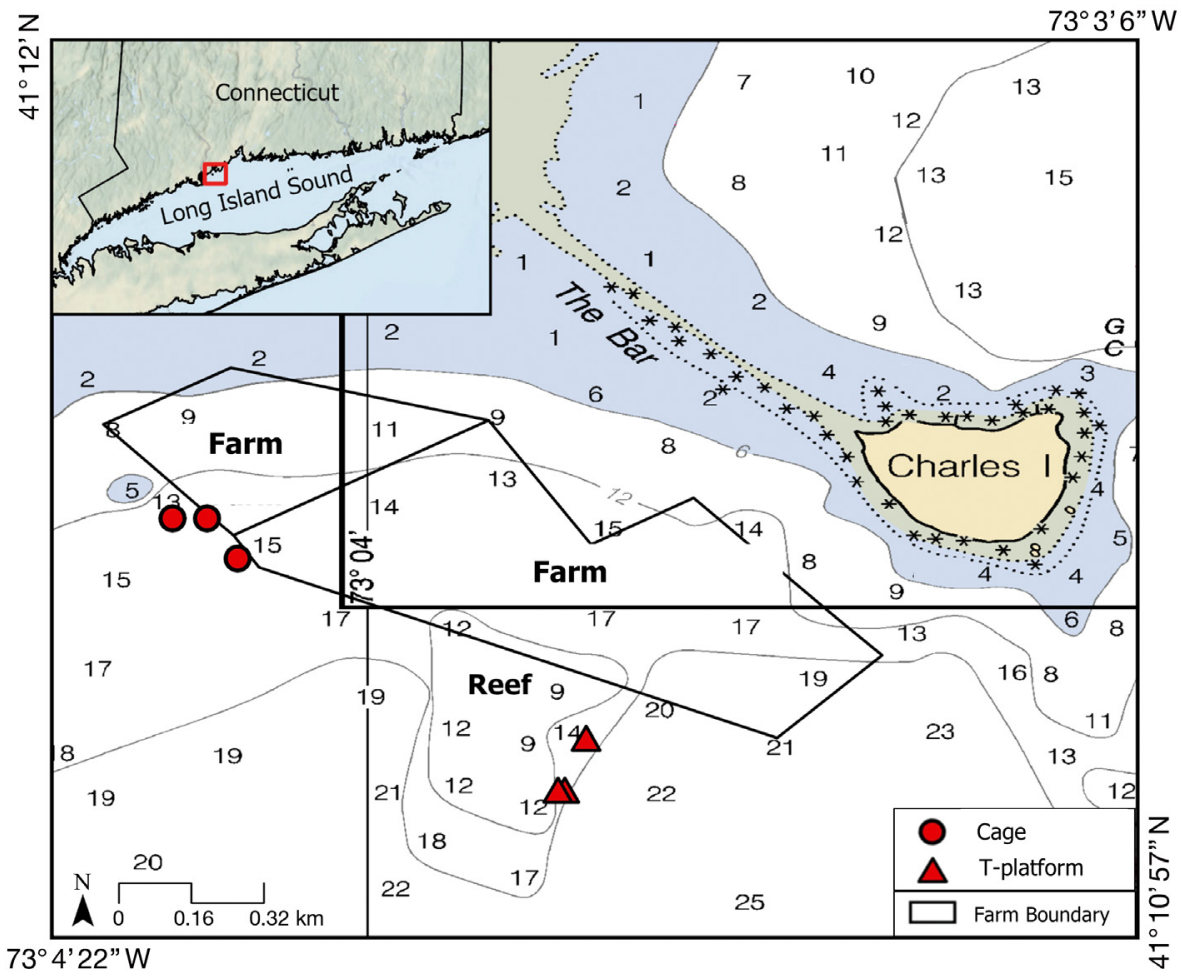

Fig. 1. Study sites included an on-bottom eastern oyster aquaculture cage farm and a natural cobble and boulder reef. Insert shows location of sites in central Long Island Sound near Milford, Connecticut, USA. The cage farm was adjacent to a commercial shellfish farm that contained 140 oyster aquaculture shelf-and-bag style bottom cages. Cameras were deployed on oyster cages at the cage farm and on T-platform stands adjacent to boulders on the rock reef. Numbers indicate depth in meters. Blue areas delineate shallow water and asterisks indicate rocks 
cages (permitted for up to 250 cages) was co-located at the farm site, thus the total number of cages in the immediate vicinity of the cage farm site was $>140$ during all sampling events. Two 'spare' study cages were placed at the farm as replacements in the event of gear loss. The rock reef was horseshoe-shaped, patchy, and covered $0.25 \mathrm{~km}^{2}$ of seafloor. Cobble and boulders composed up to $70 \%$ of the reef substrate (Mercaldo-Allen et al. 2011). Three boulders were selected for study within the reef. Water depths at all sites ranged from 4.6 to $6 \mathrm{~m}$ at high tide. Temperature and salinity recorded on the cage farm and rock reef during the study period ranged from 18 to $22.8^{\circ} \mathrm{C}$ and from 26.2 to $28.1 \mathrm{ppt}$.

\subsection{Camera methods and environmental parameters}

Video was recorded using GoPro Hero ${ }^{\circledR}$ Silver 3+ cameras. Cameras were time-synched and programmed to record at 30 frames of video per second, $1920 \times 1080$ pixels, 10 megapixel, wide angle lens (firmware v03.02). Each camera was contained within a polycarbonate waterproof case with a $\mathrm{BacPac}^{\circledR}$ attachment that accommodated a timer or double battery pack. A Polar Pro ${ }^{\circledR}$ magenta filter, with a 0.5 stop reduction in exposure, was affixed to each camera lens to reduce green coloration of video caused by factors such as the natural attenuation of light in water, and by phytoplankton and particulate material in the water column. This filter improved video clarity and contrast and eliminated the need for post-processing, but reduced light and restricted the water depth at which we were able to collect useful video records without artificial light.

We tested several methods for attaching cameras to oyster cages. Initially, a flexible spring mount was placed at a cage corner, but resulted in excessive camera motion during cage deployment and retrieval. Instead, a flexible mount system was devised using $\sim 0.6 \mathrm{~m}$ of $2.22 \mathrm{~cm}$ flex marine wet exhaust and water hose coupled with a section of $0.84 \mathrm{~cm}$ outer diameter PVC pipe, which provided stability and shock absorption to cameras during cage handling. This side mount, which hung $30.5 \mathrm{~cm}$ off the cage corner, provided a view of 2 cage sides and the interface between cage and seafloor (Fig. 2A). To collect video of the upper cage surface, we initially tested a fisheye lens by mounting a camera on a bridle positioned above the cage looking down, but poor water clarity and lens distortion prevented viewing the entire cage surface. Instead, the final top camera mount was po- sitioned like a periscope at the cage corner, providing a view of the entire horizontal cage surface (Fig. 2A). Methods were developed for applying 2 different video collection strategies on oyster cages: interval and continuous video recording. Camera deployments were conducted weekly during summer 2017 to test various camera mounting configurations and recording strategies, and here we report on interval video collected on 11 July and 3 and 23 August, and continuous video collected on 14 August.

Characteristics of current patterns, light intensity, and seawater conditions were monitored during camera deployments to evaluate whether changes in fish abundance related to environmental parameters. One TCM-1 tilt current meter (Lowell Instruments) deployed at each site measured current speed $(\mathrm{cm}$ $\mathrm{s}^{-1}$ ), magnetic direction (-13.5 magnetic declination), and eastward and northward flow $\left(\mathrm{cm} \mathrm{s}^{-1}\right)$ over $1 \mathrm{~min}$ intervals. A 5-point running mean was used to derive smoothed records of current speed and eastward and northward flow. $\mathrm{HOBO}{ }^{\circledR}$ pendant temperature and light data loggers (Onset Computer) were deployed to document light illuminance at depth (lumens $\mathrm{m}^{-2}$ ) and seawater temperature $\left({ }^{\circ} \mathrm{C}\right)$ over 5 min intervals. Salinity (ppt) was measured at both sites after camera deployment and retrieval using a handheld YSI Pro30 ${ }^{\circledR}$ salinity, conductivity, and temperature meter.

\subsection{Interval video recording}

Three shelf-and-bag style, commercially available oyster aquaculture bottom cages (Ketcham Supply) were added to an existing active commercial oyster cage farm in early May 2017 and removed at the end of the field season in September (Fig. 1). Study cages were placed $45.7 \mathrm{~m}$ apart on the farm. The cages were constructed of $11.43 \mathrm{~cm}$ mesh, heavy-duty, 8-gauge vinyl-coated wire, with reinforced $3.81 \mathrm{~cm}$ wire mesh feet, to which 10 bricks were added to each cage foot for ballast (Fig. 2A). Cages measured $1.22 \times 0.91 \times 0.61 \mathrm{~m}$ and had 3 shelves, each holding 2 bags of oysters ( 6 bags total per cage). Bags, made from $2.3 \mathrm{~cm}$ plastic mesh, measured $1.07 \mathrm{~m}$ long by $0.52 \mathrm{~m}$ wide, and were stocked during May with 300 seed oysters that measured $2.5 \mathrm{~cm}$. On Day 1 of camera deployments, each individual study cage was mechanically hauled onto the deck of the boat, 2 cameras were attached, and each cage was redeployed. Recording took place on Day 2, and on Day 3, the cages were brought back on deck, cameras were retrieved, and the cages were returned to the seafloor. Mid-season, cages and bags were cleaned with 

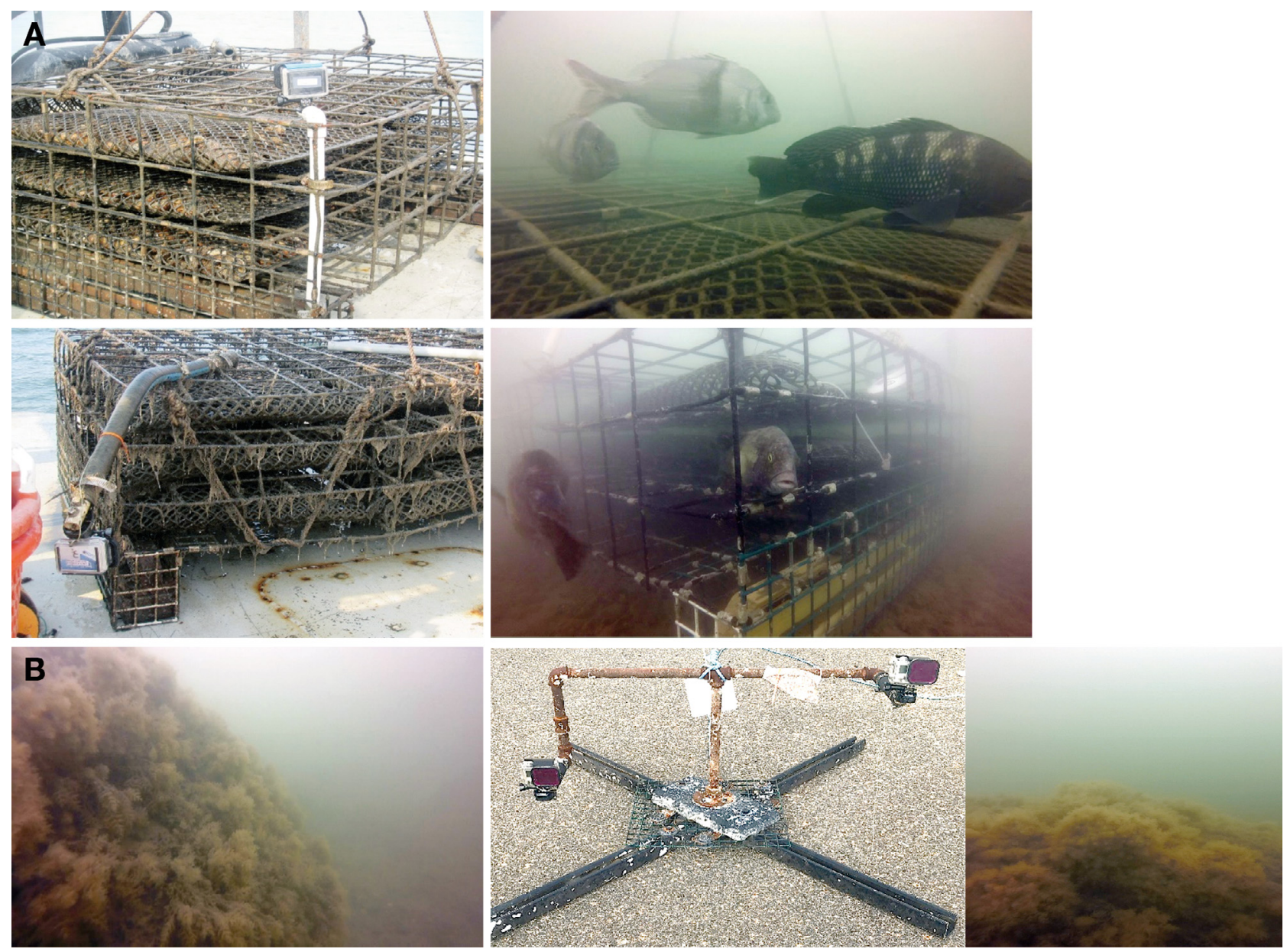

Fig. 2. Camera deployment and example video frames. (A) Two cameras were directly attached to the shelf-and-bag style oyster aquaculture cages; one showed images across the cage top, the second showed 2 sides of the cage and the cage-seafloor interface. (B) Two cameras were attached to minimal-structure 'T-platform' stands that were deployed adjacent to boulders on a rock reef; one showed images across the boulder top, the second showed the boulder side and boulder-seafloor interface

a power washer and the numbers of oysters was reduced to 200 per bag to account for increases in shellfish volume due to oyster growth. Cage handling methods and oyster stocking densities reflected industry practices (C. Vien pers. comm).

Interval recording was conducted using intervalometer Blink ${ }^{\circledR}$ timers (CamDo) paired with GoPro cameras to delay onset of video recording and extend battery life. Video recording began approximately $24 \mathrm{~h}$ after camera deployment on cages to reduce deployment-related disturbance effects on fish abundance and behavior. Video was recorded for $8 \mathrm{~min}$ every hour from 07:00 to 19:00 h, yielding 13 recordings per camera deployment, which enabled collection over a complete tidal cycle and most daylight hours. Video was collected during 2017 using both side and top cameras on cages at the farm site on 11 July and 3 and 23 August (Table 1).
Table 1. Dates (mm/dd/yy) when video recording (interval or continuous) and eDNA water sampling was conducted at the cage farm and rock reef sites in summer 2017

\begin{tabular}{|lll|}
\hline $\begin{array}{l}\text { Sampling } \\
\text { week }\end{array}$ & Camera recording method & $\begin{array}{l}\text { eDNA } \\
\text { sampling }\end{array}$ \\
\hline $6 / 27 / 17$ & No data & Farm \& reef \\
$7 / 11 / 17$ & Interval; farm only & Farm \\
$7 / 18 / 17$ & No data & Farm \& reef \\
$8 / 3 / 17$ & Interval; farm only & Farm \\
$8 / 14 / 17$ & Continuous; farm \& reef & Farm \& reef \\
$8 / 23 / 17$ & Interval; farm only & Farm \\
\hline
\end{tabular}

\subsection{Continuous video recording}

To collect video among boulders within the rock reef, T-platform camera mounts were designed and built that minimized added structure and enabled 
camera positioning to provide a similar perspective as the cameras mounted on the oyster cages. Each T-platform stand measured $0.46 \mathrm{~m}$ high and was constructed from pieces of threaded metal pipe with 2 mounting arms positioned $69 \mathrm{~cm}$ apart (Fig. 2B). The $\mathrm{X}$-shaped base $(0.76 \mathrm{~m})$ was assembled using a $4.1 \mathrm{~cm}$ Aickinstrut fiberglass channel with $90^{\circ}$ brackets. Vinyl-coated mesh, with $2.54 \mathrm{~cm}$ openings, was bolted to the top of the strut, and a zinc plate measuring $12.7 \times 25.4 \mathrm{~cm}$ and weighing $16 \mathrm{~kg}$ was bolted to the top of the mesh to provide ballast. A $1.3 \mathrm{~cm}$ floor flange was attached to the top of the zinc plate. Interchangeable $1.3 \mathrm{~cm}$ threaded black pipe was used to adjust the T-platform height based on the dimensions of each replicate boulder. The base was painted black to better blend in with the seafloor. One camera was positioned to record across the top boulder surface while the other camera captured one side of the boulder and the boulder-seafloor interface.

Continuous video was collected on 14 August 2017 at 3 study cages on the cage farm and 3 boulders on the rock reef (Fig. 1, Table 1). Cameras were deployed on the cage farm as described above, but with cameras set to record continuously instead of at intervals. Cameras were activated on the boat prior to attaching and deploying on cages and T-platforms. To determine where to place T-platforms, the rock reef was surveyed ahead of time using a drop camera to identify seafloor areas where boulders were most numerous. Three T-platforms with attached cameras were individually hand-lowered from the vessel using buoyed lines and placed on the seafloor. Divers then oriented each T-platform adjacent to a boulder ( 0.5-0.75 $\mathrm{m}$ in height). Selected boulders were a minimum of $10 \mathrm{~m}$ apart. Each T-platform and camera array was tethered by an individual buoy line for retrieval, posing a risk for gear loss or disturbance from boaters. To ensure T-platforms remained in place and to allow successful recovery, video was recorded while the vessel remained onsite. Video was collected for approximately $3 \mathrm{~h}$ on each cage and $2 \mathrm{~h}$ on each boulder. After video collection, T-platforms with cameras were recovered by hand-hauling buoy lines.

\subsection{Video analysis}

The Observer ${ }^{\circledR}$ XT (v14.0; Noldus Information Technology) software was employed for video scoring, as it enabled multi-video playback, inter-coder (observer) analysis, and a flexible coding scheme. Fish abundance was calculated as MaxN, defined as the maximum number of fish of a given species pres- ent in a single frame (Watson et al. 2005, Florisson et al. 2018) within a given time increment. Counting the maximum number of fish at a single time point avoids double-counting that may occur when fish swim in and out of view over the course of video collection (Wilson et al. 2015), but may underestimate total abundance since our camera setup could not capture all cage sides or the cage interior. For this reason, MaxN is considered a conservative estimate of total fish abundance (Willis \& Babcock 2000, Whitmarsh et al. 2018). For interval video samples, MaxN was calculated for each $8 \mathrm{~min}$ segment. For continuous video, MaxN was calculated at 1 min intervals. Water clarity was highly variable both between camera deployment dates and even between hours within a single camera deployment, but generally, visibility extended for the full length of the cage/boulder. To minimize bias in fish counts associated with turbidity, only fish within the immediate cage/boulder area that could be positively identified using a combination of morphological features and swimming behavior were included in counts. For quality control, a series of intercoder (inter-observer) comparisons of videos scored for MaxN were conducted and assessed using Cohen's kappa (Cohen 1960, Jansen et al. 2003). Independent video review commenced once Cohen's kappa values were above 0.8 (McHugh 2012). Video recorded in intervals were analyzed in full. Continuous videos from the cage farm were analyzed beginning from the minute that each cage was set on the seafloor, and continuous videos from the rock reef were analyzed beginning from the minute that divers swam away from the T-platform.

A qualitative assessment of organisms attached to boulders and cages was conducted to better describe habitat attributes of the cage farm and rock reef environments. Organisms attached to boulders were identified using a combination of previous diver observations, drop camera video (Mercaldo-Allen et al. 2011), and video footage from this study. When cages were on the boat deck for mounting of cameras, organisms growing on cages, oyster bags, and lines were noted and were also identified from video footage. Fish behavior associated with cages and boulders in video recordings was also qualitatively identified and described.

\section{6. eDNA sampling, processing, and analysis}

Water samples were collected for eDNA metabarcoding to compare to the species assemblage observed by camera, and additionally, to detect the 
presence of fish species in the vicinity of cages or boulders that may not have been observed in video. Water samples were collected on 3 dates (27 June, 18 July, 14 August) in 2017 at consistent sampling locations on the cage farm and rock reef, and 3 additional dates (11 July, 3 and 23 August) on the cage farm only (Table 1). A Niskin bottle was lowered to $0.5 \mathrm{~m}$ above the seafloor to collect 4 replicate $1 \mathrm{l}$ seawater samples for eDNA analysis, as described by Liu et al. (2019). Briefly, samples were kept on ice until filtration using nylon filters $(0.45 \mu \mathrm{m})$ and polycarbonate filters $(0.4 \mu \mathrm{m})$, and then frozen $\left(-20^{\circ} \mathrm{C}\right)$ until analysis. DNA was extracted with a Qiagen DNeasy Power Water Kit following the manufacturer's instructions. PCR was carried out on the 12S mitochondrial rDNA region using ecoPrimers in the GE Healthcare Illustra puRe Taq Ready-To-Go PCR beads $25 \mu$ l system (Riaz et al. 2011, Liu et al. 2019). After PCR cleanup, indexing Nextera PCR, and another PCR cleanup, next-generation sequencing was then conducted on pooled PCR amplicons on the Illumina MiSeq platform, followed by bioinformatics analysis, where steps outlined in DADA2 were followed to generate an abundance table of amplicon sequence variants. All unique DADA2 sequence variants were classified using Basic Local Alignment Search Tool (BLAST) against reference sequences in GenBank. Species identified were classified as 'abundant' or 'rare' based on read number; species that occurred in fewer than $0.1 \%$ of samples and/or whose read numbers were less than $0.1 \%$ of the total reads within an individual sample were classed as 'rare' (Stoeckle et al. 2017). The eDNA method was previously validated by comparing fish detected by metabarcoding to visual identifications in trawl collections by the Connecticut Department of Energy and Environmental Protection (Liu et al. 2019). Here, we used eDNA metabarcoding from the 3 concurrent sampling dates (Table 1) to assess species presence on the cage farm and rock reef. In addition, we report and visualize eDNA read numbers from 6 sampling dates at the cage farm (Table 1), for the subset of abundant species that are known to be dependent on structured habitat, and make qualitative comparisons with fish assemblages observed by camera at the cage farm.

\subsection{Data analysis}

The statistical software program $\mathrm{R}$ version 3.6.1 (www.r-project.org) was used to perform statistical analyses. While 7 species in total were observed across all interval recordings on the 3 dates, only 4 species were observed consistently during each of the 3 camera recording dates: black sea bass Centropristis striata, cunner Tautogolabrus adspersus, scup Stenotomus chrysops, and tautog Tautoga onitis. The daily mean abundance of each of these commonly occurring species was calculated for each date, and a repeated measures analysis of difference scores was conducted for all pairs of species across the 3 recording dates. A percentile bootstrap method was combined with the Benjamini-Hochberg method to control familywise error rate across the multiple comparisons. This method was chosen over the standard repeated measures ANOVA since the selected method does not assume normality or homoscedasticity, and has been shown to control Type I error probabilities when sample sizes are very small, as is the case here (Wilcox 2017).

The relationship between abundance of the 4 most commonly observed individual species and the environmental predictors light and current speed was explored using a running interval smoother. This method was selected over the classical least square regression method since the running interval smoother does not assume a linear relationship between species and predictor variables, and is more robust to the presence of outliers or unusual values (Wilcox 2017). The running interval smoother used here provides a measure of explanatory power and a plotted visualization, but does not generate a p-value. Mean current speeds were calculated for the same times that each interval video was collected on the 3 recording dates (11 July, 3 and 23 August) and compared to the average MaxN across the 3 cages (39 pairs of current speed and abundance for each species). Mean light intensity was calculated for the same times that each interval video was collected on 2 of the 3 recording dates (11 July, 23 August); equipment malfunction on 3 August resulted in data loss. Light intensity was compared to the average MaxN across the 3 cages (26 pairs of light intensity and abundance for each species).

The frequency of occurrence and overall abundance of individual fish species were compared in continuous video between the cage replicates and the boulder replicates in video collected on 14 August 2017. Video observations were made at 1 min intervals, and this was the temporal unit assessed for both sets of comparisons. Frequency of occurrence was assessed between 3 replicate cages and 3 replicate boulders using the Storer-Kim method for comparing independent binomial groups, and was chosen based on recommendations from a comparison of available methods in Wilcox (2017). A mean MaxN was generated by averaging across the 3 replicates in each 
location for each of the 120 min of continuous video for which there were paired observations. Overall abundance of individual fish species was then compared between cage farm and rock reef locations using a repeated measures analysis of differences scores using the same percentile bootstrap method described in the previous paragraph.

eDNA metabarcoding likely detected finfish species including those with minimal to no association with either of the benthic structured habitats that were the focus of this study. We used published literature on fish habitat preferences (Leim \& Scott 1966, Whitehead 1985, Makushok 1986, Robins \& Ray 1986, Whitehead et al. 1988, Dooley 1990, Collette \& Klein-MacPhee 2002; as referenced in Fishbase [https://www.fishbase.se]) to select the subset of 5 abundant finfish species known to be dependent on structured habitat for further examination. Given the current uncertainty around correlations between eDNA read number and fish abundance or biomass (Yates et al. 2021) and the spatiotemporal limitations of our data, we have chosen to report and visualize eDNA read number here and make qualitative comparisons with fish assemblages observed by video, but not to perform a quantitative statistical analysis of these data.

\section{RESULTS}

\subsection{Interval video recording}

A total of 7 fish species were observed at the cage farm over the course of the deployments: black sea bass, banded rudderfish Seriola zonata, butterfish Peprilus triacanthus, cunner, scup, tautog, and yellow jack Carangoides bartholomaei. Four of the species were regularly observed on all 3 dates and associated with all 3 replicate cages: black sea bass, cunner, scup, and tautog. The 3 remaining species were observed rarely: an individual banded rudderfish on a single cage on 23 August, 2 schools of butterfish (13-14 individuals) on a single cage on 23 August, and yellow jack ranging in abundance from 3 to 20 individuals on 2 cages on 23 August. Abundance of the 4 most common fish species (black sea bass, cunner, scup, tautog) associated with oyster aquaculture cages varied over time (11 July, 3 and 23 August; Fig. 3). An all-pairwise, repeated measures comparison of the 4 species across the 3 dates indicated that black sea bass had the highest abundance (all $p<0.001$ ), scup had a higher abundance than cunner $(p<0.001)$, but abundance of tautog was

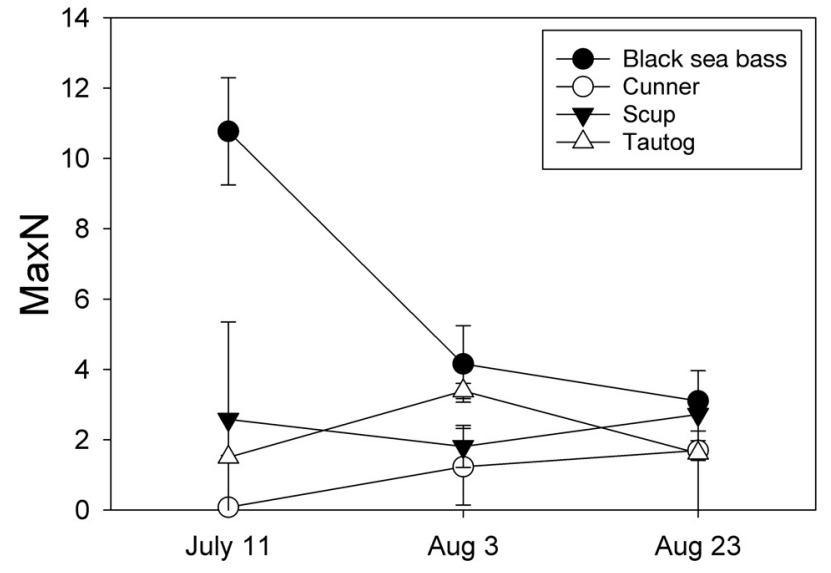

Fig. 3. Abundance of the 4 most commonly observed fish associated with oyster aquaculture cages over 3 dates where interval recording was conducted. The daily average MaxN was calculated for each cage (where MaxN was defined as the maximum number of fish of a given species present in a single frame for each $8 \mathrm{~min}$ recording segment). Symbols and error bars represent the mean \pm SD

not significantly different from either cunner $(\mathrm{p}=$ $0.068)$ or $\operatorname{scup}(\mathrm{p}=0.511)$.

The range of light and current speeds during video recording on 11 July were representative of the physical conditions in the study area (Fig. 4). Current speeds ranged from 0.362 to $14.5 \mathrm{~cm} \mathrm{~s}^{-1}$, and the periodicity of observed current speeds was consistent with tidal flow (Fig. 4A), which is typical for Long Island Sound (O'Donnell et al. 2014). The periods of time during which 8 min videos were simultaneously collected covered the full range of current speeds observed during the $2 \mathrm{~d}$ period that cameras were deployed. Light intensity (lumens $\mathrm{m}^{-2}$ ) ranged from 0 to 1292 (Fig. 4B). Similarly, the periods of time during which video was collected simultaneously are indicated by gray bars. Video was collected during the full range of observed light intensities during the camera deployment. When averaged across cages, abundance $(\operatorname{MaxN})$ of the 4 most common species illustrates how these environmental parameters were matched to species abundance (Fig. 4C)

Current speed was a poor predictor of fish abundance for all 4 of the most commonly observed species associated with the cage farm (explanatory power was 0 for all species; for data visualizations, see Fig. S1 in the Supplement at www.int-res.com/ articles/suppl/q013p277_supp.pdf). Light intensity was a better predictor of fish abundance for 3 of the 4 species, explaining $26 \%$ of the variation in black sea bass abundance, $13 \%$ of the variation in scup abundance, and $27 \%$ of the variation in tautog abundance, but was a poor predictor for cunner abun- 


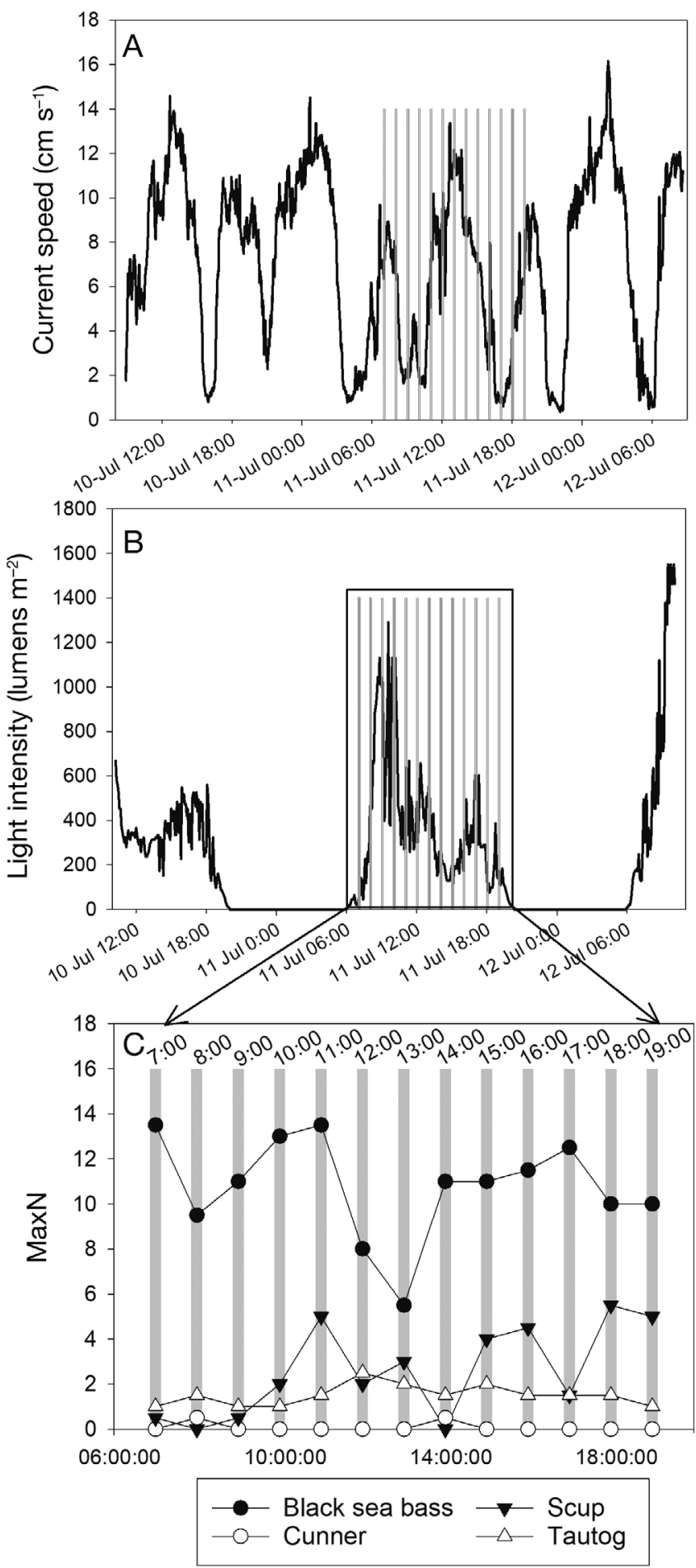

Fig. 4. Collection of environmental parameters in conjunction with video observations in July 2017. Gray bars in all panels indicate timing of video collection. (A) Black lines indicate current speed $\left(\mathrm{cm} \mathrm{s}^{-1}\right)$ measured every minute, plotted as a 5-point running smooth. (B) Black lines indicate light intensity (lumens $\mathrm{m}^{-2}$ ) measured every $5 \mathrm{~min}$. (C) Fish abundance of the 4 most commonly observed species from our full dataset; each point represents the observed MaxN during an 8 min video recording dance, with an explanatory power of 0 (see Fig. S2 for data visualizations).

\subsection{Continuous video recording}

Black sea bass were observed at the cage farm throughout continuous recording on 14 August 2017 (Fig. 5A). At least 1 individual was observed in association with 1 or more cages during every minute of the $3 \mathrm{~h}$ recording period. Black sea bass were less frequently observed at the rock reef, with individuals observed in association with 1 or more boulders in only $47 \%$ of the recording minutes $(p<0.001$; Fig. 5B). The opposite pattern was observed for cunner, which were observed more frequently on the rock reef than on the cage farm ( $p<0.001$; Fig. 5C,D). Cunner were observed in association with 1 or more oyster cages in $50 \%$ of the recording minutes, but were observed in association with 1 or more boulders in $83 \%$ of recording minutes. Scup were more frequently observed in videos collected at the cage farm ( $72 \%$ of recording minutes had 1 or more scup on at least 1 cage) versus the rock reef $(15 \%, p<0.001$; Fig. 5E,F). Tautog were also more frequently observed in videos collected at the cage farm $(69 \%$ of recording minutes had 1 or more tautog on at least 1 cage) than at the rock reef $(7 \%, \mathrm{p}<0.001 ;$ Fig. 5G,H).

Black sea bass were also observed in higher abundance on the cage farm than on the rock reef across the $2 \mathrm{~h}$ continuous videos (estimated difference 1.73; $\mathrm{p}<0.001$ ). MaxN ranged from 0 to 6 individuals across all of the oyster cage video collected, and 0 to 3 individuals across all of the rock reef videos. Cunner were observed in higher abundance on the rock reef than the cage farm (estimated difference 0.46 ; $\mathrm{p}<0.001$ ). MaxN for cunner ranged from 0 to 2 at the cage farm, and from 0 to 4 at the rock reef. Scup and tautog were observed in higher abundance at the cage farm than the rock reef (estimated difference 0.32 and 0.26 for scup and tautog, respectively; both $\mathrm{p}<0.001)$. Interestingly, the MaxN for scup had a wider range on the rock reef (0-13) than on the cage farm (0-6) due to a single unusual event at minute 83 (Fig. 5F). MaxN for tautog ranged from 0-3 at both the cage farm and the rock reef.

\subsection{Organisms attached to cages and boulders}

Direct observations of the boulders and cages enabled a qualitative description of the habitat provided by each type of structure. Boulders on the rock 

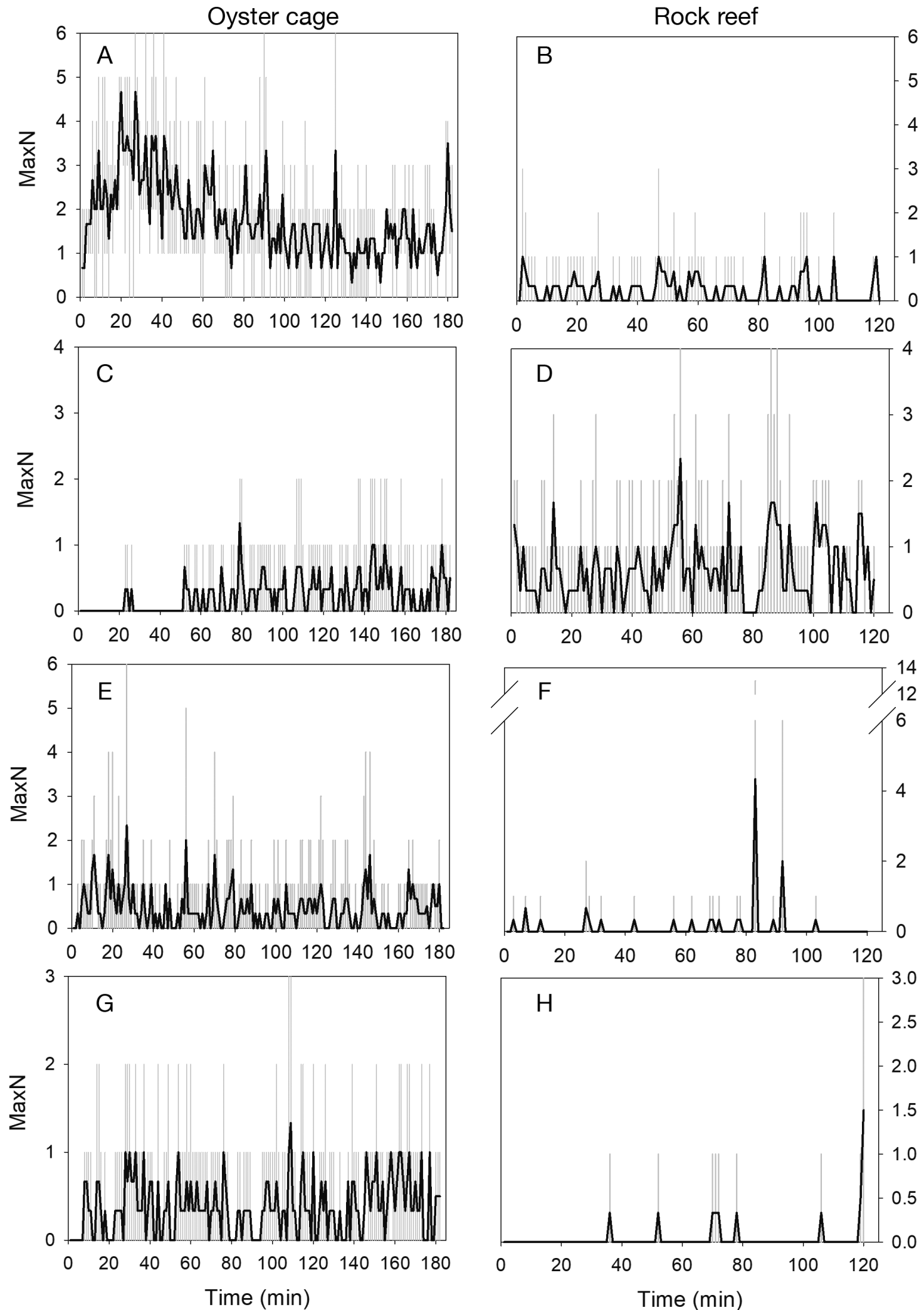

Fig. 5. Abundance of the 4 most common fish species observed during continuous video collection on 14 August 2017 . Lines indicate mean of 3 replicates, gray bars represent min and max fish observed. $(A, B)$ Black sea bass; $(C, D)$ cunner; $(E, F)$ scup; $(\mathrm{G}, \mathrm{H})$ tautog 
reef were heavily colonized with epibiotic growth consisting primarily of bushy bryozoans but were also inhabited by macroalgae, sponges, and hydroids. These communities formed dense cover adding to the vertical relief of the boulder and providing habitat for small invertebrates. Bushy bryozoans moved with current flow and were observed to provide physical protection, shade, and camouflage for small-bodied fish. Definitive identification of organisms to the species level presented a challenge on boulders due to limited visibility in videos and the inability to visually inspect surfaces. Over the course of the season, oyster cage structure, lines, mesh bags, and rigging also became encrusted with organisms on exposed interior and exterior surfaces, including bryozoans, tunicates, and sponges. Caprellid amphipods were also attached to these surfaces. Mesh bags with oysters also provided surface area for colonizing organisms and refuge for small organisms inside the cages. Colonizing organisms inhabiting cage surfaces, based on observations from video and visual inspections of cages while on deck, included spaghetti bryozoans Amathia verticillata, invasive purple bush bryozoans Bugula neritina, an unexpected invasive bryozoan (Tricellaria inopinata), invasive tunicates (Didemnum spp.), colonial hydroids (Campanularia spp.), and caprellid amphipods (Caprella spp.), and the algae seen on the cages included red algae (Porphyra spp.), green string lettuce Ulva intestinalis, devil's whip Chordaria flagelliformis, and red wooly grass Agardhiella subulata.

\section{4. eDNA metabarcoding}

We detected 42 fish species via eDNA metabarcoding analysis (Table 2). Seventeen were classified as 'abundant' and 25 were classified as 'rare'. Detections of 9 species were site specific, and all of these were classified as 'rare' species. American eel Anguilla rostrata, yellow jack, and 2 freshwater species, common carp Cyprinus carpio and redbreast sunfish Lepomis auratus, were found in water samples from the cage farm only. Five species, American fourspot flounder Hippoglossina oblonga, Atlantic cod Gadus morhua, northern stargazer Astroscopus guttatus, northern kingfish Menticirrhus saxatilis, and skilletfish Gobiesox strumosus, were unique to samples from the rock reef. Three species (naked goby Gobiosoma bosci, winter flounder Pseudopleuronectes americanus, and yellow jack) could not be classified without ambiguity using eDNA alone due to similarities in sequences among related species. In these cases, identifications were augmented based on known geographic range and information on local distribution in the Connecticut Department of Energy and Environmental Protection trawl survey data (Liu et al. 2019), with other possible identifications shown in the table footnotes. Black sea bass, butterfish, cunner, scup, tautog, and yellow jack (Table 2) were detected both by eDNA analysis and in video footage. A solitary banded rudderfish, recorded in video at a single cage on 23 August, was not detected by eDNA metabarcoding on any of the 3 dates on which the reef and farm were both sampled or during the additional 3 dates eDNA was collected at the farm. Original fastq files with metadata are deposited in the NCBI Sequence Read Archive (NCBI BioProject ID PRJNA498484).

Five of the abundant species were classified as 'structure-dependent' based on information on habitat preferences available in the literature: black sea bass, cunner, rock gunnel Pholis gunnellus, seaboard goby Gobiosoma ginsburgi, and tautog, and read number for these species over time at the cage farm is provided in Fig. 6. While we routinely observed scup in video, we chose not to include them in this category because scup commonly occur in schools on structured as well as open sandy habitats (Steimle et al. 1999), thus scup read number could reflect populations associated with either habitat type within the larger embayment. Black sea bass were detected on 5 of the 6 dates, tautog and cunner on 4 dates, and seaboard goby and rock gunnel on 2 dates. When compared to camera observations, there were instances where species were seen on camera but not detected by eDNA metabarcoding: on 11 July, cunner daily average MaxN was 0.08 , on 3 August, tautog daily average MaxN was 3.4, and on 23 August, black sea bass daily average MaxN was 3.1 , but in these 3 instances, no sequences were detected in the corresponding eDNA metabarcoding samples.

\section{DISCUSSION}

\subsection{Video observations}

Using off-the-shelf components, action cameras, and commercially available accessories, we designed and deployed an effective, inexpensive system for collecting video on oyster aquaculture cages that enabled estimates of fish abundance under variable field conditions. We also developed and field-tested a T-platform stand for mounting cameras adjacent to boulders that added minimal addi- 
Table 2. Fish species detected using eDNA metabarcoding from seawater samples collected on 3 dates (given as mo/d) near the cage farm and rock reef are indicated by gray shading. In cases where species have similar DNA sequences and cannot be distinguished, the species known to be present based on geographic range are listed with other possible identifications shown in the footnotes. Species that were also observed in video during the 2017 field season are indicated in bold, and species visually observed in or falling out of cages on deck are noted with an asterisk

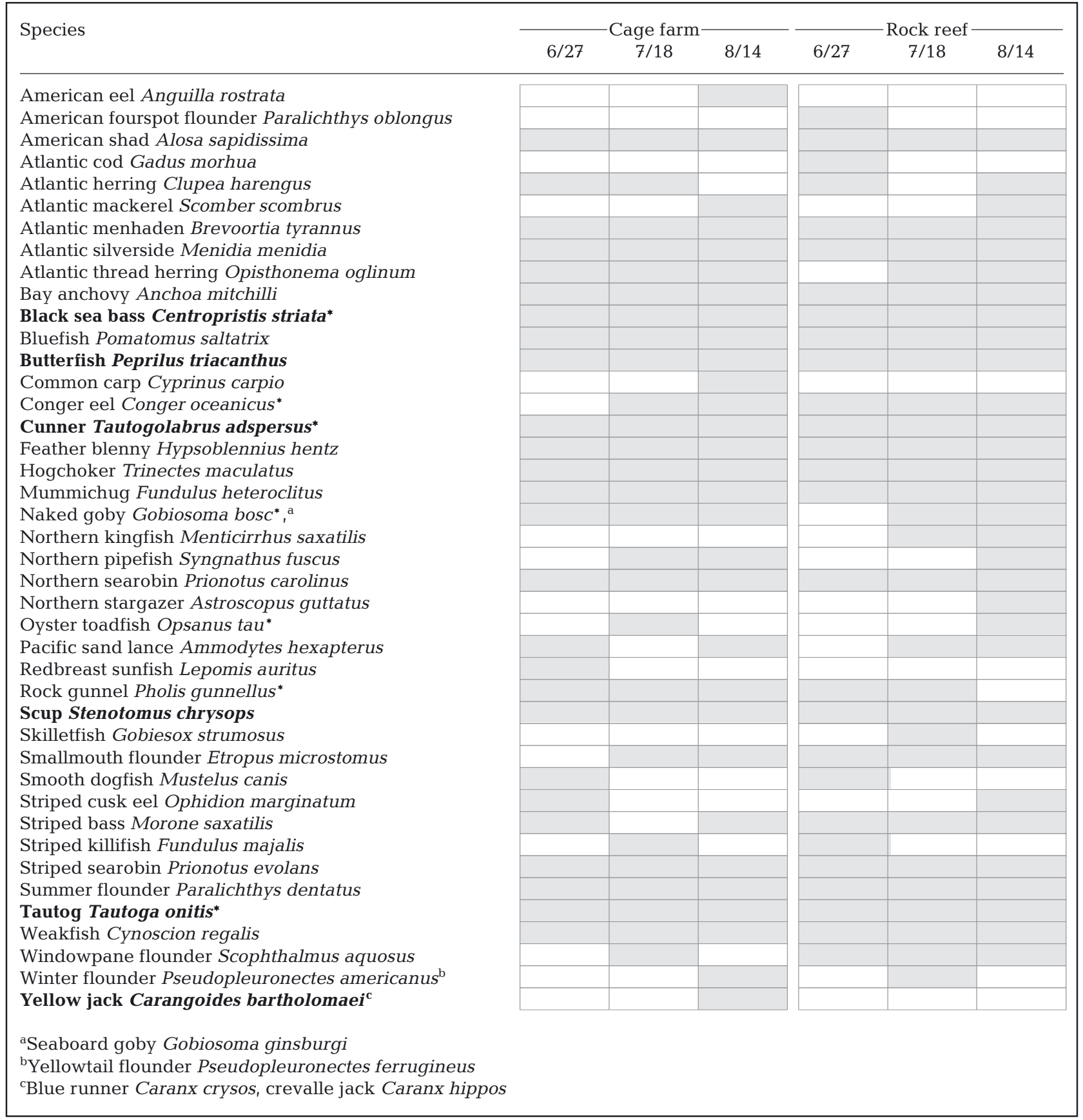

tional structure while providing a field of view similar to that of cage-mounted cameras, and allowed comparison of fish use of aquaculture gear and rock reef habitat. Quality of video imaging allowed definitive identification of fish by species for MaxN estimates of fish abundance.
Video observations confirmed that oyster aquaculture cages provided habitat for fish in the marine environment much like that of natural structured seafloor. Seven fish species were observed at the cage farm, with 3 temperate reef fishes (black sea bass, cunner, and tautog) and a demersal species 


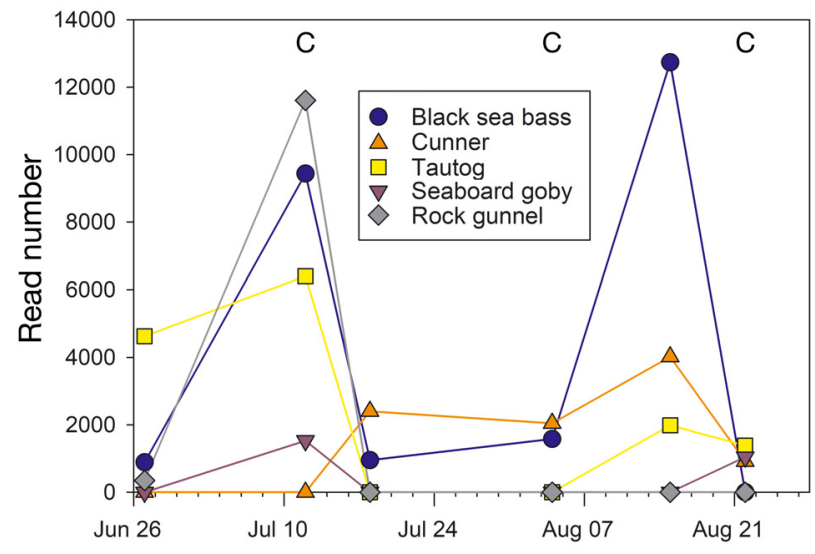

Fig. 6. eDNA read numbers for 5 structure-dependent species at the cage farm. The letter $\mathrm{C}$ indicates dates on which video recording also took place

(scup) most abundant. While mean fish abundance varied over time, fish were consistently associated with oyster aquaculture cages, with the 4 most abundant species present across all 3 dates sampled.

Results from the continuous video recording conducted at the cage farm and rock reef sites indicated that the same fish species were observed on both aquaculture gear and boulders, but frequency of observation and abundance varied between locations. Black sea bass, scup, and tautog were observed more frequently and at higher abundance in association with the cage farm, while cunner were observed more frequently and at higher abundance in association with boulders on the rock reef. We note that our conclusions must be constrained by the spatial limitations of this proof-of-concept study; the lack of replication across multiple cage farms or rock reefs limits the ability to generalize these results beyond the locations studied here. Our results were consistent with a trapping study in Rhode Island, USA, that compared fish abundance near oyster cages, natural rock reefs, and an artificial reef. The authors of that study reported tautog and scup to be more abundant near cages, and cunner to occur in higher numbers near reef structures, while black sea bass demonstrated no discernable preference among structure types (Tallman \& Forrester 2007). It is noteworthy that the use of cameras in our study, instead of traps, enabled detection of fish specifically associated with cages or boulders and not just fish in the local environment. In Great Bay Estuary, New Hampshire, USA, Glenn (2016) used volumetric sampling to quantify epibiotic communities in oyster cages, on eelgrass, mudflat, and oyster reef habitats, in an area lacking rock reef structure. Significantly more fish were associated with cages, and $97 \%$ of those fish were cunner. In the absence of natural rock reef environments, oyster cages may provide important habitat for shelter-dependent cunner. Interestingly, Liu et al. (2019) observed higher read numbers of black sea bass, tautog, and cunner on the same rock reef when compared to the cage farm we sampled. This result could have been due to higher numbers of small fish on the reef when compared to the farm, as large numbers of small fish may be expected to produce similar amounts of eDNA as fewer large fish. It is also worth noting that the video collected here was only a few hours of footage, whereas eDNA sampling is believed to reflect longer time scales (e.g. days; Stoeckle et al. 2021).

\subsection{Organisms attached to cages and boulders}

Differences in the physical attributes and colonizing organisms associated with cages and boulders may account for variable patterns in species abundance around these structures. Epifaunal communities that contribute to habitat value have been reported to differ in composition and coverage on natural versus artificial structures (Glasby 1999, Connell 2000). Rigid mesh cages offered higher surface area and interior volume while solid boulders were more thickly colonized on surfaces with epifauna that added depth and complexity but lacked small interstices that serve as shelter space from predators, flow, and light. Macroalgae and large bushy bryozoans inhabiting boulders offered dense cover and camouflage that might provide better protection to small-bodied cunner than the larger interstices of the cage structure. Cunner are known to be reliant on dense vegetation and cover associated with boulders for foraging and refuge (Tupper \& Juanes 2017, O'Brien et al. 2018). Although body size and life history stage were not quantified, we generally observed a broader range of fish sizes and variety of life history stages on the cages. Quantifying these differences would be a valuable future research direction.

The use of commercially available intervalometer timers and environmental data loggers enabled monitoring of natural variability in current and light conditions that may have occurred on short timescales and could affect fish abundance. Dynamic tidal conditions in Long Island Sound produced variable current speeds and visibility in video footage recorded within the same cage and sampling day. Variations in current speed have been shown to affect distribution and foraging behavior of structure-oriented species 
like cunner and tautog (Auster 1989). These species have shown high affinity for habitat that provides shelter from current flow (Olla et al. 1974, 1975). High current velocity affects the ability of fish to maneuver (Auster 1989) and may increase the use of structured habitat as flow refuge, potentially resulting in higher fish abundance. In a previous study documenting field observations of temperate reef species, fluctuating current speeds were found to affect the size class composition of fish feeding on surfaces or moving in the water column (Auster 1987). In that study, spatial distribution among cunner of all size classes appeared unaffected by current speeds of 0.25 knots $\left(12.9 \mathrm{~cm} \mathrm{~s}^{-1}\right)$ while at 0.75 knots $(38.6 \mathrm{~cm}$ $\mathrm{s}^{-1}$ ), only a subset of the largest fish was able to maneuver. During the 3 video recording dates in our study, current speed was a poor predictor of fish abundance, although we note that the limited number of recording dates and small geographic scale constrain our ability to draw definitive conclusions from this analysis. Since currents at the cage farm never exceeded 0.35 knots $\left(18 \mathrm{~cm} \mathrm{~s}^{-1}\right)$, fish may have been less likely to seek out cages as a flow refuge, and this may explain why we detected no relation between current speed and fish abundance on the farm. While light intensity was a better predictor of individual species abundance than current speed for black sea bass, scup, and tautog, the variation in abundance explained was at most $27 \%$, which is relatively modest. Increased statistical power from additional camera deployments over a longer time frame may be necessary to clarify how current velocity and light levels may affect fish abundance and movements near boulders and cage structures.

\section{3. eDNA metabarcoding}

eDNA provided a valuable complement to video data collection. Six of the 7 fish species observed in video were captured by eDNA sampling. A solitary banded rudderfish, recorded in video at a single cage on 23 August, was not detected in any of the eDNA samples, but both cameras and eDNA may have undersampled rare species (Kelly et al. 2017), which is a problem common to sampling methods available for structured habitats (Jagielo et al. 2003). As expected, eDNA sampling detected a greater variety of species (42) than video (7). The eDNA detection list included more species (33) common to both sites and fewer species unique to a single site $(4$ and 5 at the farm and reef, respectively). This was not surprising given the close geographic proximity of the 2 loca- tions. eDNA enabled a broader picture of species that may have been influenced by the presence of structured habitat, such as large pelagic and/or predatory fish (e.g. striped bass Morone saxatilis, weakfish Cynoscion regalis), which inhabit the water column but have limited direct association with the structure itself, as well as benthic species that inhabit the seafloor under and around cages (e.g. hogchoker Trinectes maculatus, naked goby, rock gunnel).

At the same time, detection of a species' DNA near structured habitat does not indicate that the species was influenced by the presence of the structure. Seasonally transient or migratory species (e.g. Atlantic thread herring Opisthonema oglinum, shad Alosa sapidissima, skilletfish), present for short durations, may move through an area without being observed in video, but also not interacting with structure. Detection of 25 rare species in the study embayment suggests that eDNA analysis has the sensitivity to identify species infrequently encountered via traditional survey methods (Rees et al. 2014, O'Donnell et al. 2017, Liu et al. 2019) and may be useful for describing species composition in difficult to sample environments such as rock reefs and shellfish farms, as well as distinguishing fish assemblages associated with different structures (Port et al. 2016, Jeunen et al. 2019).

We have accordingly limited our presentation of quantitative eDNA metabarcoding data (i.e. read number) to species that have been shown in published literature to be closely associated with structured habitat. Given the general absence of structure in central Long Island Sound, we had higher confidence that the read numbers obtained for this reduced species list were reflective of populations local to the sites we sampled than for the broader list of species detected by metabarcoding. Significant correlation between read number and fish abundance has been reported in the literature (e.g. Di Muri et al. 2020), and others have observed significant correlation between read number and biomass (Stoeckle et al. 2021). It could be anticipated that read number would more closely correlate with biomass, since eDNA production (by shedding and/or metabolic processes) by many small fish could be similar in quantity to a much smaller number of larger fish (Yates et al. 2021). The 2-dimensional nature of video makes estimates of fish size unreliable, thus we were unable to calculate biomass of observed fish, which would potentially have been a better metric for comparison to read number. These unknowns make it challenging to interpret observed differences in species composition on cage farms between camerabased MaxN and eDNA-based read numbers. 


\subsection{Limitations of camera and eDNA methods}

Video assessments of oyster cages and boulders provide an opportunity to visualize fish abundance and movements in the natural environment. Although this methodology improves upon more extractive sampling, video observations of fish can be constrained by light availability (i.e. daytime sampling only), turbidity (restricting observations to the immediate cage area), and the limited view of the camera itself (i.e. fish inside cages are hidden from view). Several species residing primarily inside the cage or on the seafloor were not recorded on video. Conger eel Conger oceanicus, naked goby, oyster toadfish Opsanus tau, and rock gunnel, which fell out of cages onto the boat deck during camera deployment or retrieval, were detected by eDNA, but not observed in video. Small-bodied and/or benthic species, like naked goby and rock gunnel, were most likely absent from video due to their modest body size and a propensity to burrow into sediments. Despite these considerations, we found a high level of concurrence $(>0.8)$ in the same sets of videos scored independently by 2 coders based on comparison of Cohen's kappa and have confidence in our ability to identify and count fish in videos.

Accessibility of action cameras and enthusiasm for citizen science has generated interest in deploying cameras on shellfish farms and identified the need for optimization of camera placement. Oyster cages are large relative to the perspective afforded by a single camera, and fish interact with all surfaces. In our study, water clarity in turbid estuarine conditions was frequently poor enough that this problem could not be resolved by placing a single camera far enough away to record the full cage. Using 2 cameras, we were able to effectively view and document fish abundance across the cage top and 2 cage sides. Employing multiple cameras to assess fish abundance has previously been reported to increase the sensitivity and accuracy of MaxN estimates by reducing error related to differences in fish abundance among camera views (Whitmarsh et al. 2018).

Although eDNA metabarcoding documented a greater diversity of species than observed with video, this approach too has constraints, and more direct comparisons of read numbers to independent estimates of fish abundance and/or biomass are needed to better interpret their quantitative meaning. Differences in methodological details, along with variable fish behavior, residency time, and rates of eDNA production and decay may influence the interpretation of the sequence abundance. For example, efficiency of
eDNA amplification for individual fish species may vary with primer choice, while fish activity, such as the rapid movement of transitory species through an area, may leave insufficient eDNA for extraction (Stat et al. 2019). Another uncertainty of the eDNA method is that detection of DNA does not always indicate the presence of an animal at the time of sample collection. Detection of eDNA from freshwater species (common carp, redbreast sunfish) suggests incidental introduction from the nearby Wepawaug and Housatonic Rivers, rather than an association with either structured habitat. Additionally, eDNA methodology yields no information about individual body size or life history stages (Thomsen \& Willerslev 2015), which is a valuable indicator of whether habitat supports additional fish production or just serves as an attractant. We used eDNA as an approach to provide a more complete accounting of species composition than video alone, and speculate that it may also provide useful semi-quantitative data, particularly when combined with a priori knowledge of species habitat preferences. When used together, these complementary methods were effective for describing fish assemblages and abundance on oyster farms and rock reef habitats.

\subsection{Qualitative behavioral observations}

While abundance estimates provide an empirical measure of fish associated with cage and boulder structure as we demonstrated here, future studies including behavioral analysis of fish activity can more precisely define the functional role of these habitats and provide insights into species-habitat interactions. Although this present proof-of-concept study was too limited in scope and sample size for analysis of behavioral patterns, we made qualitative observations that identified classes of behavior for future studies. These fish-habitat behaviors include: foraging (grazing and picking at organisms growing on cage mesh and rigging lines), station keeping (small fin movements to hold place in currents, flow refuges, shelters), courtship (large males pursuing females that take refuge in or under cages), territorial displays (aggressive chasing or biting), and spawning (release of gametes). Describing specific behaviors displayed by fish near cages and boulders is the next step in defining the role these structures play in providing habitat to fish throughout their life history. Detailed accounting of fish behavior associated with aquaculture gear may help inform permitting and management decisions regarding siting of shellfish farms and potential benefits of gear to fish and invertebrate communities. 


\subsection{Conclusions}

We demonstrate the value of using video from action cameras to effectively document fish assemblages and abundance associated with oyster aquaculture cages and natural boulder habitat. Analysis of video demonstrated that we could accurately identify fish according to species, determine abundance using MaxN counts for each species, and visualize how fish are using cages and boulders as habitat. Our methods are readily accessible to citizen scientists and shellfish growers with an interest in underwater viewing of marine communities associated with aquaculture gear. Using video to census fish in and around oyster aquaculture cages could be applied in other aquaculture settings to monitor fish use of gear as habitat. Collection of water samples from the cage farm and rock reef for eDNA metabarcoding provided a valuable complementary method, and identified many additional fish species present in the vicinity of the study areas but not observed in video. Video observations and eDNA metabarcoding, used in concert, offer a novel approach to describing fish assemblages and abundance associated with oyster aquaculture cage and boulder habitat.

Acknowledgements. We thank David Carey, Kristin DeRosia-Banick, and Shannon Kelly of the State of Connecticut, Bureau of Aquaculture; shellfish growers Robert Granfield, Gary Salce of G \& B Shellfish and Charles Viens of Charles Island Oyster Farms for access to leased shellfish beds; NOAA divers Calandrea DeCastro, Mark Dixon, Keith Golden, Jerry Prezioso, and Barry Smith for dive support. Arthur Allen of the Coast Guard Office of Search and Rescue for analysis of current meter data; John Pinkowski and Fisher Island Oysters for the loan of seed oysters; Robert Alix and Eileen Bates for support of field operations; David Hudson of Norwalk Maritime Aquarium for technical assistance; and NOAA's Northeast Fisheries Science Center and Office of Aquaculture for funding. Field operations were conducted aboard the Milford Laboratory's 15 m NOAA RV 'Victor Loosanoff.' Use of tradenames does not imply endorsement.

\section{LITERATURE CITED}

Archer A, Reitsma J, Murphy D (2014) A comparison of bottom and floating gear for growing American oysters (Crassostrea virginica) in southeastern Massachusetts. Marine Extension Bulletin, Cape Cod Cooperative Extension. https://www.capecodextension.org/wp-content/ uploads/2013/02/Comparison-of-Bottom-and-FloatingGear-for-Growing-American-Oysters-in-SE-Mass.pdf

Auster PJ (1987) The effect of current speed of the small scale spatial distribution of fishes. NOAA Symp Ser Undersea Res 2:7-16

Auster PJ (1989) Species profiles: life histories and environmental requirements of coastal fishes and invertebrates
(North Atlantic and Mid-Atlantic) - tautog and cunner. US Fish Wildl Serv Biol Rep 82(11.105). US Army Corps of Engineers, TR EL-82-4

Auster PJ, Lindholm J, Schaub S, Funnell G, Kaufman LS, Valentine PC (2003) Use of sand wave habitats by silver hake. J Fish Biol 62:143-152

Cohen JA (1960) Coefficient of agreement for nominal scales. Educ Psychol Meas 20:37-46

Collette BB, Klein-MacPhee G (eds) (2002) Bigelow and Schroeder's fishes of the Gulf of Maine, $3^{\text {rd }}$ edn. Blackburn Press, Caldwell, NJ

Connell SD (2000) Floating pontoons create novel habitats for subtidal epibiota. J Exp Mar Biol Ecol 247:183-194

Cullen DW, Stevens BG (2017) Use of an underwater video system to record observations of black sea bass (Centropristis striata) in waters off the coast of Maryland. Fish Bull 115:408-418

DeAlteris JT, Kilpatrick BD, Rheault RB (2004) A comparative evaluation of the habitat value of shellfish aquaculture gear, submerged aquatic vegetation and a non-vegetated seabed. J Shellfish Res 23:867-874. https://digital commons.uri.edu/favs_facpubs

Di Muri C, Lawson Handley L, Bean CW, Li J and others (2020) Read counts from environmental DNA (eDNA) metabarcoding reflect fish abundance and biomass in drained ponds. Metabarcoding Metagenomics 4:e56959

Dooley JK (1990) Pomatomidae. In: Quero JC, Hureau JC, Karrer C, Post A, Saldanha L (eds) Check-list of the fishes of the eastern tropical Atlantic (CLOFETA), Vol 2. JNICT, Lisbon, p 721-722

Erbland PJ, Ozbay G (2008) A comparison of the macrofaunal communities inhabiting a Crassostrea virginica oyster reef and oyster aquaculture gear in Indian River Bay, Delaware. J Shellfish Res 27:757-768

Florisson JH, Tweedley JR, Walker THE, Chaplin JA (2018) Reef vision: a citizen science program for monitoring the fish faunas of artificial reefs. Fish Res 206:296-308

Forrest BM, Keeley NB, Hopkins GA, Webb SC, Clement DM (2009) Bivalve aquaculture in estuaries: review and synthesis of oyster cultivation effects. Aquaculture 298: $1-15$

García-Charton JA, Pérez-Ruzafa Á (1998) Correlation between habitat structure and a rocky reef fish assemblage in the southwest Mediterranean. Mar Ecol 19:111-128

Geraldi NR, Bacheler NM, Kellison GT (2019) Methoddependent influence of environmental variables on reef fish assemblages when comparing trap and video surveys. Mar Ecol 40:e12538

Getchis TS (2005) An assessment of the needs of Connecticut's shellfish aquaculture industry. Connecticut Sea Grant Publication CTSG-05-02:1-12. https://seagrant. uconn.edu/2005/01/01/shellfish-aquaculture-industryassessment/

Glasby TM (1999) Differences between subtidal epibiota on pier pilings and rocky reefs at marinas in Sydney, Australia. Estuar Coast Shelf Sci 48:281-290

Glenn ME (2016) A comparison of macrofaunal and algal communities in oyster aquaculture gear, an eelgrass bed, oyster reef, and a mud flat in Great Bay Estuary, New Hampshire. MSc thesis, University of New Hampshire, Durham, NH

Jagielo T, Hoffmann A, Tagart J, Zimmermann M (2003) Demersal groundfish densities in trawlable and untrawlable habitats off Washington: implications for the estimation of habitat bias in trawl surveys. Fish Bull 101:545-565. 
https://spo.nmfs.noaa.gov/content/demersal-groundfishdensities-trawlable-and-untrawlable-habitats-washing ton-implications

Jansen RG, Wiertz LF, Meyer ES, Noldus LPJJ (2003) Reliability analysis of observational data: problems, solutions, and software implementation. Behav Res Methods Instrum Comput 35:391-399

Jeunen GJ, Knapp M, Spencer HG, Lamare MD and others (2019) Environmental DNA (eDNA) metabarcoding reveals strong discrimination among diverse marine habitats connected by water movement. Mol Ecol Resour 19: $426-438$

Kelly RP, Closek CJ, O'Donnell JL, Kralj JE, Shelton AO, Samhouri JF (2017) Genetic and manual survey methods yield different and complementary views of an ecosystem. Front Mar Sci 3:283

Leim AH, Scott WB (1966) Fishes of the Atlantic Coast of Canada. Bull Fish Res Board Can 155:1-485

Letessier TB, Juhel JB, Vigliola L, Meeuwig JJ (2015) Lowcost small action cameras in stereo generates accurate underwater measurements of fish. J Exp Mar Biol Ecol 466:120-129

Liu L, Wikfors GH, Rose JM, McBride RS, Milke LM, Mercaldo-Allen R (2019) Application of environmental DNA metabarcoding to spatiotemporal finfish community assessment in a temperate embayment. Front Mar Sci 6:674

Makushok VM (1986) Pholididae. In: Whitehead PJP, Bauchot ML, Hureau JC, Nielsen J, Tortonese E (eds) Fishes of the North-eastern Atlantic and the Mediterranean, Vol 3. UNESCO, Paris, p 1124-1125

Marenghi F, Ozbay G, Erbland P, Rossi-Snook K (2010) A comparison of the habitat value of sub-tidal and floating oyster (Crassostrea virginica) aquaculture gear with a created reef in Delaware's Inland Bays, USA. Aquacult Int 18:69-81

McHugh ML (2012) Interrater reliability: the kappa statistic. Biochem Med (Zagreb) 22:276-282

Mercaldo-Allen R, Goldberg R, Clark PE, Kuropat CA (2011) Observations of juvenile American lobsters, Homarus americanus, on a rock-reef in Long Island Sound. Northeast Nat 18:45-60

Mercaldo-Allen R, Clark P, Liu Y, Meseck S, Milke L, Redman D (2020) Macrofaunal assemblages on oyster aquaculture and rock reef habitat in Long Island Sound. N Am J Aquac 82:92-100

O'Brien BS, Mello K, Litterer A, Dijkatra JA (2018) Seaweed structure shapes trophic interactions: a case study using a mid-trophic level fish. J Exp Mar Biol Ecol 506:1-8

O'Donnell J, Wilson RE, Lwiza $\mathrm{K}$, Whitney $\mathrm{M}$ and others (2014) The physical oceanography of Long Island Sound. In: Latimer JS, Tedesco MA, Swanson RL, Yarish C, Stacey PE, Garza C (eds) Long Island Sound: prospects for the urban sea. Springer, New York, NY, p 79-158

O'Donnell JL, Kelly RP, Shelton AO, Samhouri JF, Lowell NC, Williams GD (2017) Spatial distribution of environmental DNA in a nearshore marine habitat. PeerJ 5:e3044

Olla BL, Bejda AJ, Martin D (1974) Daily activity, movements, feeding, and seasonal occurrence in the tautog, Tautoga onitis. Fish Bull 72:27-35

Olla BL, Bejda AJ, Martin D (1975) Activity, movements, and feeding behavior of the cunner, Tautogolabrus adspersus, and comparison of food habitats with young tautog, Tautoga onitis, off Long Island, New York. Fish Bull 73: 895-900
Port JA, O'Donnell JL, Romero-Maraccini OC, Leary PR and others (2016) Assessing vertebrate biodiversity in a kelp forest ecosystem using environmental DNA. Mol Ecol 25: $527-541$

Rees HC, Maddison BC, Middleditch DJ, Patmore JRM, Gough KC (2014) The detection of aquatic animal species using environmental DNA - a review of eDNA as a survey tool in ecology. J Appl Ecol 51:1450-1459

Riaz T, Shehzad W, Viari A, Pompanon F, Taberlet P, Coissac E (2011) ecoPrimers: inference of new DNA barcode markers from whole genome sequence analysis. Nucleic Acids Res 39:e145

Robins CR, Ray GC (1986) A field guide to Atlantic coast fishes of North America. Houghton Mifflin, Boston, MA

Scuderi B, Chen X (2019) Production efficiency in New England's oyster aquaculture industry. Aquac Econ Manag 23:45-64

Shumway SE, Davis C, Downey R, Karney R and others (2003) Shellfish aquaculture - in praise of sustainable economics and environments. World Aquac 34: 15-18. https://www.was.org/Magazine/Vol/34/4\#.X67 mI2hKjIU

Stat M, John J, DiBattista JD, Newman SJ, Bunce M, Harvey ES (2019) Combined use of eDNA metabarcoding and video surveillance for the assessment of fish biodiversity. Conserv Biol 33:196-205

Steimle F, Zetlin C, Berrien P, Johnson D, Chang S (1999) Essential fish habitat source document. Scup, Stenotomus chrysops, life history and habitat characteristics. NOAA Tech Memo NMFS-NE 149. https://repository.library.noaa. gov/view/noaa/3154

Stoeckle MY, Soboleva L, Charlop-Powers Z (2017) Aquatic environmental DNA detects seasonal fish abundance and habitat preference in an urban estuary. PLOS ONE 12:e0175186

Stoeckle MY, Adolf J, Charlop-Powers Z, Dunton KJ, Hinks G, VanMorter SM (2021) Trawl and eDNA assessment of marine fish diversity, seasonality, and relative abundance in coastal New Jersey, USA. ICES J Mar Sci 78: 293-304

Stoner AW (2004) Effects of environmental variables on fish feeding ecology: implications for the performance of baited fishing gear and stock assessment. J Fish Biol 65: 1445-1471

Tallman JC, Forrester GE (2007) Oyster grow-out cages function as artificial reefs for temperate fishes. Trans Am Fish Soc 136:790-799

Thomsen PF, Willerslev E (2015) Environmental DNA — an emerging tool in conservation for monitoring past and present biodiversity. Biol Conserv 183:4-18

Thomsen PF, Kielgast J, Iversen LL, Møller PR, Rasmussen M, Willerslev E (2012) Detection of a diverse marine fish fauna using environmental DNA from seawater samples. PLOS ONE 7:e41732

Tupper M, Juanes F (2017) Testing foraging arena theory: the effects of conspecific density and habitat type on time and energy budgets of juvenile cunner. J Exp Mar Biol Ecol 487:86-93

Ulrich TL, Bonar SA (2020) Inexpensive, underwater filming of rare fishes in high definition. Fisheries 45: 122-130

Watson DL, Harvey ES, Anderson MJ, Kendrick GA (2005) A comparison of temperate reef fish assemblages recorded by three underwater stereo-video techniques. Mar Biol 148:415-425 
Watson DL, Harvey ES, Fitzpatrick BM, Langlois TJ, Shedrawi G (2010) Assessing reef fish assemblage structure: How do different stereo-video techniques compare? Mar Biol 157:1237-1250

Whitehead PJP (1985) FAO species catalogue, Vol 7. Clupeoid fishes of the world (suborder Clupeoidei). An annotated and illustrated catalogue of the herrings, sardines, pilchards, sprats, shads, anchovies and wolf-herrings. Part 1. Chirocentridae, Clupeidae and Pristigasteridae. FAO Fish Synop 125. FAO, Rome

Whitehead PJP, Nelson GJ, Wongratana Y (1988) FAO species catalogue, Vol 7. Clupeoid fishes of the world (Suborder Clupeoidei). An annotated and illustrated catalogue of the herrings, sardines, pilchards, sprats, shads, anchovies and wolf-herrings. Part 2. Engraulidae. FAO Fish Synop 125. FAO, Rome

Whitmarsh SK, Huveneers C, Fairweather PG (2018) What are we missing? Advantages of more than one viewpoint to estimate fish assemblages using baited video. R Soc Open Sci 5:171993

Editorial responsibility: Brett Dumbauld,

Newport, Oregon, USA

Reviewed by: 3 anonymous referees
Wilcox RR (2017) Introduction to robust estimation and hypothesis testing, $4^{\text {th }}$ edn. Elsevier Academic Press, London

Willis TJ, Babcock RC (2000) A baited underwater video system for the determination of relative density of carnivorous reef fish. Mar Freshw Res 51:755-763

Wilson KL, Allen MS, Ahrens RNM, Netherland MD (2015) Use of underwater video to assess freshwater fish populations in dense submerged aquatic vegetation. Mar Freshw Res 66:10-22

Yamamoto S, Masuda R, Sato Y, Sado T and others (2017) Environmental DNA metabarcoding reveals local fish communities in a species-rich coastal sea. Sci Rep 7:40368

Yates MC, Glaser DM, Post JR, Cristescu ME, Fraser DJ, Derry AM (2021) The relationship between eDNA particle concentration and organism abundance in nature is strengthened by allometric scaling. Mol Ecol 30: 3068-3082

Zarco-Perello S, Enríquez S (2019) Remote underwater video reveals higher fish diversity and abundance in seagrass meadows, and habitat differences in trophic interactions. Sci Rep 9:6596

Submitted: August 21, 2020

Accepted: May 20, 2021

Proofs received from author(s): July 7, 2021 